\title{
Concept Reconstruction and Guarantee Standard of Antitrust Law in Professional Sports*
}

\author{
Chenlin Ying \\ School of Law \\ Xi'an Jiaotong University \\ Xi'an, China 710049 \\ Xi'an Jiaotong University City College \\ Xi'an, China 710061
}

\begin{abstract}
The problem of monopoly in professional sports has been the obstacle to the sound development of sports industry in China. Along with the acceleration of the commercialization of the professional sports industry in China, the dual attributes of the monopoly and competition of the professional sports are becoming more and more obvious. Its particularity brings about the focus of attention for the regulations in anti-monopoly law. On the one hand, the "Commerciality" in professional sports determines the antimonopoly law should applicable to the relevant market and in the meanwhile regulate it; on the other hand, because of the "Sports" in professional sports, certain monopoly behavior which is based on "competitive balance" should be exempted. Therefore, the regulations of professional sports antimonopoly law should be established on the basis of the serious assessment of application and exemption system. It can effectively regulate the relevant market, but not hinder the development of professional sports industry.
\end{abstract}

Keywords-professional sports; anti-monopoly; regulation; strategy

\section{INTRODUCTION}

The problem of monopoly in professional sports has been the obstacle to the sound development of China sports industry. However, instead of the concept of professional sports, the expression of competitive sports is adopted in China "Sports Law". Since the implementation of the antimonopoly law of China from 2008, the controversy about the application and exemption of anti-monopoly of professional sports has never stopped. This argument mainly focuses on the particularities of professional sports. The absolute application of Antitrust Law in the sports industry is meeting the challenge of the "reasonable principle". The exemption rules to a certain extent, is considered to be able to effectively adapt to the special attributes of professional sports and thus promote the development of sports industry. With the acceleration of the development of sports industry in China, the rapid penetration of commercial factors in the sports industry makes it possible to get rid of the constraints of the traditional planned economic system. "Commercial

*Fund Project: 1.Shaanxi Social Science Fund Project (2014F05) 2. Ministry of Education Humanities and Social Science Fund Project (17XJA890002) quality" gives rise to the existence of special symbiotic and competitive relationship between the professional sports players, which is to follow both the general market competitive rules and abide by the unique sports rules, showing the complexity of monopoly and competition [1]."

The No. 46th document [2], promulgated by the State Council in 2014, requests that the acceleration of the transformation of government functions, strengthening of the market supervision, and creation of a market environment for the orderly and equal participation shall be carried out in the development of China sports industry. It especially emphasizes that sports industrial resources trading platform shall be established in the optimization of the market environment to innovate market operation mechanism and to further promote fair competition. This shows that the fair value is to be attached with great importance in China's professional sports industry and the anti-monopoly has become an unavoidable problem. In 2012, the first antimonopoly case in China sports was held a hearing in Guangzhou Intermediate People's Court. Liu Xiaowu, the plaintiff, sued the Football Association of Guangdong Province and the Zhuchao Company for their exclusive agreement in violation of the Antitrust Law of the People's Republic of China. The agreement approves that Zhuchao Company has the exclusive ownership of the related intellectual property rights and all commercial exploitation rights of Futsal League football match of Guangdong Province. This not only reflects the realistic contradiction between the new and the old system in the replacement of China professional sports system, but also shows that the important significance of the anti-monopoly on the development of the professional sports industry.

\section{PARTICULARITIES OF ANTITRUST LAW OF PROFESSIONAL SPORTS}

If the professional sport is regarded as a unified market which can be regulated, then its products shall be "athletic contests which is a combination of ornamental value, entertainment and technical integration of sports for the public consumption [3]." Compared with other traditional products, a professional sport has its own particularity. The 
particularity will leave a question open to the universally relevance of the Antitrust Law.

First of all, the sports contest is quite different from the predictable values of traditional products. The greatest attraction of consumers is precisely the uncertainty of the results of the sports contest. This uncertainty requires that at least each side of the parties in the same level of competition shall hold the same competitive abilities in theoretical significance. If the competitive parties are overmatched, then the result from consumer based on subjective judgment and the success of the expected outcome of the game is possible, while the contest itself has lost its potential consumer desire, and therefore it has also shaken the basis of consumer products as sports competition. This proves that the uncertainty is of great significance to maintain the "consumable feature" of sports competition. Moreover, from the point of view of sports spirit, "if the opponent is completely out of the game, then the full meaning of the fight will be destroyed [4]." That is to say, the core value of the sports industry comes from the competition equilibrium [5]." However, the professional sports industry still follows the general rules of the economic market, and the superior resource integration caused by competition is easy to break this competition equilibrium. For example, "the traditional strong teams" will have a relative advantage in attracting outstanding athletes and coaches and furthermore this advantage will strengthen its position as "strong team" as well. To this end, methods such as the restriction of the athletes' flowage and the league matches admittance restriction will be adopted to maintain the competition equilibrium in the professional sports.

Secondly, the competitive mode of professional sports is different from that of the traditional industry and the purpose of the professional sport is not to exclude the competitors from the market. In general, professional sports are described as "the coexistent sports of competition and cooperation [6]". There is no need to explain the "Competitiveness". The essence of any professional sports is to achieve effective confrontation. Competition or confrontation itself constitutes a process of providing products of professional sports industry. But at the same time, the competitiveness of the professional sports also determines that any independent market players cannot achieve the absolute exclusion of other market because the competition cannot be completed independently by any one party and it needs mutual cooperation from the two sides. Therefore, the "cooperative feature" has also formed the basic way of providing the competition product of the professional sports industry. This kind of cooperation is not restricted to the two sides especially when the professional sports market has scale effect. In the entire sports league or a national level, it is required to coordinate with each other to form an effective competition system. In order to improve the competitiveness of sports competitions, or to achieve the above-mentioned "uncertainty", these institutional arrangements need be considered to some extent in weakening the competition. It is also required "to ensure the cooperation to a certain extent in strength and development of the alliance [7]", for example, to adopt a consistent restriction system of athletes qualification.

Thirdly, the private property attributes of professional sports products, which have some nonprofit natures in a certain degree, are different from those of traditional commodity. The professional products belong to "the quasipublic products". According to Samuelson theory, a typical public product shall have characteristics of "the noncompetitiveness" and "non-exclusiveness". The noncompetitiveness refers to that the user's utilization of the product will not affect the quality of other users' utilization of this product; while the non-exclusiveness shows that user cannot exclude the utilization of the products when the products have been provided to customers. For professional sports products, the game tickets and broadcast rights restrictions will limit to a particular user audience, that is to say, those who have not paid the equal price of the product cannot enjoy the same quality products, which is different from the typical public products. However, the additional sports spirit of the professional sports products determine that professional sports shall be part of the precious assets owned by the whole nation. Supports of sports undertakings and antitrust exemption from governments of all countries are based on the consideration of the sports industry public welfare. Therefore, professional sports products possess obvious nonprofit natures although they are not pure public products, and can be considered as "quasi-public products [8]".

It can be found that, in order to provide a higher quality of professional sports products, the existing certain specific systems of the professional sports industry do meet the objective requirements of limit competition and shall be governed by the law of anti-monopoly. However, the particularity of professional sports is different from the traditional commodity attributes, and the restriction of competition in many cases is not a monopoly for the purpose. The specific application of antitrust exemption shall be taken into consideration and the behavior of limit competition existing in professional sports shall be treated differently.

\section{APPLICATIONS AND EXEMPTION OF THE ANTITRUST LAW TO THE PROFESSIONAL SPORTS}

The double attribute of "Sports" and "Commercial" of professional sports is the premise and foundation to introduce the Antitrust Law. It is the inevitable result to take the professional sports as independent industry along with the effective investment of the commercial capital. The professional sports have already become a fact of "surpassing the inherent concept and scope of sports competition, promoting the formation of sports industry and sports market. It also has a positive effect on economic development and investment and has become a new area of economic development [9]." In this case, as a regulation means of economic market, the Antitrust Law is applicable to the professional sports industry undoubtedly. Around the world, there are plenty of legislations on antitrust against profession sports, such as Canadian "Competition Law", which clearly stipulates that the following cases shall be regarded as committing crimes: the applications of antitrust 
law on professional sports, the unreasonable restrictions of others to participate in professional sports, or the additional unreasonable conditions, or the unreasonable restrictions of others to choose to participate in the professional league club through negotiation.

Therefore, there is no controversy that the Antitrust Law be comprehensively applied in professional sports industry. But in fact, the universality of antitrust regulation theory has been under restrictions. For national security and economic development considerations, the antitrust law of all countries usually stipulates the exceptions of the application of antitrust law, which is antitrust exemption. The particularity of special industry and its important role in the national economy allowing the industry to have a monopoly state are usually considered concerning the scope of exemption. Taking into account the differences between professional sports and traditional industries, especially its special attributes of "the coexistence of competitiveness and cooperation", each country will often implement the necessary exemption of professional sports to promote the sound development of their own professional sports. But the Article VII of "Anti-monopoly Law of the People's Republic of China"-- "With respect to the industries which are under the control of by the State-owned economic sector and have a bearing on the lifeline of the national economy or national security and the industries which exercise monopoly over the production and sale of certain commodities according to law, the State shall protect the lawful business operations of undertakings in these industries.", is defined as the industry of antitrust exemption. According to the strict law explanation, professional sport shall not be exempted and shall be applicable to Anti-monopoly Law. Any effective competition which may constitute the act of limiting shall be governed and regulated by the Anti-monopoly Law. However, this conclusion is obviously contradictory to the particularities of the aforementioned professional sports, which have constrained the development space of the professional sports industry. This requires the necessary coordination in the existing system framework to make judgments on the situation of specific professional sports monopoly. "It is important to promote the mutual competition commercially in professional sports team and no damages within or between teams shall be available [10]."

It shall be admitted that the application and exemption of Anti-monopoly Law on professional sports is far from the simple either-or logic relations. Although the particularity of the professional sport has provided anti-monopoly exemption with rational basis, the rationality shall be established on the basis of the full benefit assessment. For example, the anti-monopoly exemption system of the United States has been adopted as a reference system to improve China's existing professional sports industry. If it is analyzed from the evolution process, it is still reflected as a dynamic path of balance of interests. The attitudes of the United States in the early days on the professional sports is mainly giving support by establishing anti-monopoly exemption system for professional sports league, that is "to avoid the high operating costs of professional sports because of excessive competitions between the clubs so as to ensure the effective supply and quality of professional sports products [11]." With the acceleration of commercialization of professional sports in the United States, the negative influence of the monopoly behavior beyond the rational range began to emerge, and attentions on the effects of regulations of the Antitrust Law on professional sport have been paid. The scope of anti-monopoly exemption gradually narrows in keeping the monopoly of professional sports in a flexible and adjustable state. It can be considered that the state of monopoly which can be regulated constitutes the basis of Antimonopoly Law applicable in the professional sports industry.

The comprehensive application of the application and exemption of the Anti-monopoly Law has assured that the restricted competitive behavior of the professional sports is always kept within the limits of the law. Therefore, the application and exemption of the Anti-monopoly Law of professional sports is a continuous game developing process. The comprehensive applications of the both will not only guarantee the realization of the effective control of the professional sports industry, but also will not stop its good development. At this point, we can establish the basic idea of anti-monopoly for the professional sports, and in view of the commercial features of the professional sports, "Antimonopoly Law" can be applied to the restricted competitive behavior in the professional sports. Although professional sports have not been defined as an exemption industry in China's "Anti-monopoly Law", maintaining the necessary "competitive balance" is the premise and basis for the development of the industry in consideration of the physical attributes of professional sports, therefore, the reasonable monopoly in the professional sports. Hence, the reasonable monopoly behavior existing in professional sports shall be exempted. This needs collection and analysis of monopoly behaviors existing in the professional sports industry to make sure that which monopoly behaviors to be exempted and which monopoly behaviors to be regulated.

\section{MONOPOLY BEHAVIORS IN PROFESSIONAL SPORTS}

The judgment of the monopoly behavior in the professional sports should maintain the spirit and value of the traditional sports, but also meet the requirements of economic development and law compliance. According to the provisions of China's Antitrust Law, monopoly behavior refers to the behavior of "exclusion and restriction of competition", which includes the monopoly agreement; the abuse of market dominant position; the operator has or may have the effect of excluding and restricting competition. It can be found that China's "Antitrust Law" is mainly for the economic monopoly behavior, which is not uncommon in the professional sports. For example between the club signed a horizontal monopoly agreements to restrict players free flow and salary Club abuse of market dominance wanton improve match ticket prices, in the provision of the game also forced tying of other goods, even malicious refusal to deal, control the result of the match, for different regions of the audience take differential treatment and so on.

In addition, the administrative monopoly has been regarded as the main contradiction in the process of anti- 
monopoly in China's professional sports. Influenced by the long term planned economy in sports field, the administrative monopoly is particularly prominent in the professional sports industry. In the atmosphere of "national wide system", the national government has become the biggest promoter and beneficiary of the sports development, directly or indirectly involved in the management of professional sports. Exclusion or restriction of competition has become the main form of administrative monopoly in professional sports. China's "Sports Law" has established the basic structure for the professional sports management system, and each administrative department has a wide range of power, which has decision-making power to a certain degree on the daily management of professional sports and the rules of the system. This will give rise to the fact that the administrative department is easy to interfere with the normal operation of professional sports through the administrative behavior, which will result in the restriction of effective competition of the market access, athletes flowing and the broadcast rights. One of the most typical examples is the Fenglu incidents of 2008, which is that Guangdong Fenglu team got outstanding academic honors in the National Basketball League and got the admittance assessment qualifications to $\mathrm{CBA}$ according to the implementation plan of the Chinese men's basketball professional league club, but the team only got 1 vote in the subsequent committee voting, limited to CBA access places, and Guangdong Fenglu lost the promotion opportunity of CBA. The Chinese Basketball Association refused the access of Fenglu to the club, and because of the uniqueness of the CBA, Fenglu club lost the opportunity of taking part in the highest level of basketball competition in China. The enforcement of administrative monopoly is more dangerous than that of economic monopoly. It is inevitable in many cases. Therefore, "Under the background of China's reform of the administrative and construction of a service type government, reform in China sports field also is launched based on the principle of "Separating public service units from government, separating government functions from enterprise management, and government regulation separating from management" [13].

It is thus obvious that the monopoly behavior in professional sports is complex, and almost all operation and maintenance in the professional sports will have restriction of competition and consequently lead to monopoly behavior. Judging from the results analysis, these monopoly behaviors has indeed hindered the effective competition, but whether it will damage the interests of specific subject or not does not have a high degree of probability. Even the same kind of monopolistic behavior is consistent with the elements of action, but there are still differences in the implementation of the purpose or effect. For example, limiting the athletes flowing may be considered as a way of keeping "competitive balance", and may also be thought as for the purpose of "local protectionism". Although the action itself has caused the loss of athletes' rights and interests, the value orientation of the two is not the same as that of the professional sports industry. That is to say, the Anti-monopoly Law is not absolute for the application and exemption of professional sports, and has a strong pertinence to the specific monopolistic behavior. It shall be judged on the basis of specific rules and regulations.

\section{REGULATION PRINCIPLES OF PROFESSIONAL SPORTS MONOPOLY}

In the long-term practice of professional sports, the application of the particularity of the professional sports on Antimonopoly Law has developed the two core principles of "the Per Se Illegal Principle" and "Reasonable Principle", which have provided important reference value to the application and exemption of anti-monopoly law in professional sports. "The per se illegal principle" is based on the illegality of specific monopoly behavior. If the monopoly behavior in essence is the purpose for restriction of competition, regardless of how well it works, it shall be regulated by the Anti-monopoly Law, which is very similar to the "red flag principle" in tort law of net contents. The "red flag principle" is an exception application of the "safe harbor principle", which is usually applied to the network service providers. If the content provided by the network service provider is tort, the network service provider shall bear the corresponding liability. However, in order to avoid the over-burden liabilities of the network service providers and hindering the development of the network industry, the "safe harbor principle" has been legislated to weaken the burden of network service providers, which is usually referred to as the "Notification - delete" obligations. But if the infringement of the network content is obvious, as obvious as the red flag, then the network service providers cannot be exempted of infringement by "safe harbor principle". "The per se illegal principle" can be applied in the obvious dangerous monopoly behavior, such as to control the game outcome by the abuse of dominant market position, malicious refusal to deal and tying behavior.

On the contrary, the "reasonable principle" is usually applied to the monopoly behavior with "fuzziness" or "controversies". This kind of monopoly behavior has the characteristics of restriction of competition, but it does not necessarily have any harmful results, for example, the horizontal monopoly agreements on athletes' salary reached between clubs in order to protect the competitiveness among the professional sports industry. The important significance of the "reasonable principle" is to determine the monopoly behavior which is beyond the monopoly law, which makes it possible to exempt some reasonable monopoly behavior in professional sports.

The "per se illegal principle" can provide the expected results in the behavior model, and can provide the necessary stable guidance for the professional sports industry. The "reasonable principle" can be flexible to the complicated restriction of competition in the professional sports industry and can avoid the mechanical feature of the regulated method. Therefore, the integration of the "per se illegal principle" and "reasonable principle" shall to be the rational choice of the anti-monopoly of China's professional sports. Of course, the legislation shall be established first to clarify the connotation and the applicable scope of the relevant principles and to give effective support to the application and 
exemption of the anti-monopoly of the professional sports industry.

\section{CONCLUSION}

The problem of monopoly in professional sports has been the obstacle to the sound development of China sports industry. The professional sports industry has its own particularity. The products values of professional sports are different from that of traditional industries. This determines that the exemption issue of the professional sports out of the united application be considered. The behaviors of economic monopoly and administrative monopoly in professional sports shall be distinguished and the application and exemption of Anti-monopoly Law shall be unified. The employment of the integration of "the Per Se Illegal Principle" and "Reasonable Principle" can not only regulate the monopoly behavior but also can avoid hindering the sound development of the professional sports industry.

\section{REFERENCES}

[1] Wei Pengjuan. Exploration of the Anti-monopoly Exemption System for Professional Spo [J]. Journal of Physical Education, 2008(6):18

[2] "Several Opinions on Accelerating the development of sports industry to promote sports consumption," the State Council promulgated the (National Development (2014) No. 46).

[3] Zhu Liqiong. Study on the Characteristics and the Future Road of the Professional Sports [J]. Journal of Kunming University, 2012(6):104

[4] Stephen Weatherill. Fair Play Please!: Recent Developments in the Application of EC Law to Sport [M]. Beijing: Law Press, 2006

[5] Tang Zijun. A Study of the Optimal Scales of Professional Sports Leagues from the Perspective of the Antitrust Law. [J]. Journal of Physical Education, 2012(2) : 60

[6] Song Jianying, Fan Wei. A Study of China Anti-monopoly Law on Regulations and Exemption of Professional Sports [J]. Heilongjiang Researches on Higher Education, 2011(12):94

[7] Wu Yuling. The Issue of Anti-monopoly in Professional Sports[J]. Journal of Beijing Polytechnic University (Social Science edition), 2008(5):47

[8] Hu Lijun. A Study on Characteristics of China Professional Sports [J]. Journal of Military Sports, 2015 (2):4

[9] Li Yanling. On the Construction of Ideas and Functions Realization of Market Access of Chinese Professional Sports [J]. China Sports and Science, 2012 (2):3

[10] Wu Yuling. Curb the evil Market: US Antitrust Policy Interpretation [M]. Nanjing: Nanjing University Press, 2007 edition

[11] Zheng Zhiqiang. Market Features of Professional Sports [J] Journal of Xi'an Institute of Physical Education, 2008(6): 16

[12] Pei Yang. Application of Antitrust Laws to Access System of Professional Sport Leagues: Comment of Feng Lü Case [J]. Journal of Tianjin University, 2008 (6):482

[13] Zhang Bing. Out Government Center Logic: Theory and Practice about Separating Management Reform of Chinese Professional Sports[J]. Journal of Sports and Science, 2014 (2):24 